\section{MULTIPLE RANKINE TOPPING CYCLES}

by

Jon D. McWhirter

Argonne National Laboratory-West

Engineering Division

P.O. Box 2528

Idaho Falls, ID 83402-2528
RECEIVED

MAR 131996

O STI

The submitted manuscript has been authored

by a contractor of the U.S. Government

under contract No. W-31-109-ENG-38.

Accordingly, the U.S. Government retains a

nonexclusive, royalty-free license to publish

or reproduce the published form of this

contribution, or allow others to do so, for

U. S. Government purposes.

Paner to ho C.-1...:und on the

July 1995

*Work supported by the U.S. Department of Energy, Reactor Systems, Development and Technology, under Contract W-31-109-Eng-38. 


\section{DISCLAMMER}

Portions of this document may be illegible in electronic image products. Images are produced from the best available original document. 


\author{
Multiple Rankine Topping Cycles \\ Jon D. McWhirter \\ Special Term Appointee, Argonne National Laboratory \\ and \\ Assistant Professor, College of Engineering, Idaho State University \\ Campus Box 8060, Pocatello, ID 83402
}

\begin{abstract}
The efficiency of a Rankine cycle is primarily determined by the temperatures of heat addition and rejection. However, no working fluid has been identified which will operate in a Rankine cycle over an extremely wide temperature range. Multiple Rankine topping cycles offer a technique for achieving high thermal efficiencies in power plants by allowing the use of several working fluids. This paper gives a history of Rankine topping cycles, presents an analysis for the calculation of the overall efficiency of a three-module multiple Rankine cycle, and presents results from a case study for a sodium-mercury-water cycle.
\end{abstract}

\author{
NOMENCLATURE \\ $\eta \quad$ efficiency \\ $\dot{\mathrm{Q}}$ heat transfer rate \\ W mechanical power \\ $\mathrm{T}$ temperature
}

\title{
DISCLAIMER
}

\begin{abstract}
This report was prepared as an account of work sponsored by an agency of the United States Government. Neither the United States Government nor any agency thereof, nor any of their employees, makes any warranty, express or implied, or assumes any legal liability or responsibility for the accuracy, completeness, or usefulness of any information, apparatus, product, or process disclosed, or represents that its use would not infringe privately owned rights. Reference herein to any specific commercial product, process, or service by trade name, trademark, manufacturer, or otherwise does not necessarily constitute or imply its endorsement, recommendation, or favoring by the United States Government or any agency thereof. The views and opinions of authors expressed herein do not necessarily state or reflect those of the United States Government or any agency thereof.
\end{abstract}




\author{
Multiple Rankine Topping Cycles \\ Jon D. McWhirter \\ Special Term Appointee, Argonne National Laboratory \\ and \\ Assistant Professor, College of Engineering, Idaho State University \\ Campus Box 8060, Pocatello, ID 83402
}

\begin{abstract}
The efficiency of a Rankine cycle is primarily determined by the temperatures of heat addition and rejection. However, no working fluid has been identified which will operate in a Rankine cycle over an extremely wide temperature range. Multiple Rankine topping cycles offer a technique for achieving high thermal efficiencies in power plants by allowing the use of several working fluids. This paper gives a history of Rankine topping cycles, presents an analysis for the calculation of the overall efficiency of a three-module multiple Rankine cycle, and presents results from a case study for a sodium-mercury-water cycle.
\end{abstract}

\title{
NOMENCLATURE
}

$\eta \quad$ efficiency

$\dot{\mathrm{Q}}$ heat transfer rate

$\dot{W}$ mechanical power

T temperature 


\section{INTRODUCTION}

The modern, state of the art, combined cycle power generation plants typically employ gas turbines with heat recovery steam generators delivering the gas turbine exhaust heat to a supercritical steam cycle. Newer installations are operating with net efficiencies just over 50\%, with incremental efficiency improvements anticipated with materials advances. Alternatives to such plants are desirable because of the possible impacts of greenhouse gas emissions and waste heat generation. Molten carbonate fuels cells are presently being tested as one alternative. Since these machines are not heat engines, they are not bound by the Carnot cycle efficiency [Kartha and Grimes, 1994].

The need for greater efficiency from fossil plants will intensify as fossil fuel resources become more scarce, and if concerns over greenhouse gas emissions increase. A higher efficiency reduces the amount of fossil fuel resources consumed, greenhouse gas emitted, and waste heat released per unit of power produced.

\section{BACKGROUND AND HISTORY OF RANKINE TOPPING CYCLES}

Rankine topping cycles have been employed in the past, with a mercury Rankine cycle as the topping cycle. Figure 1 shows a typical temperature-entropy (T-S) diagram arrangement for such a plant. A total of six of these plants were built in the United States between 1928 and 1949 [Hackett, 1951]. The best of these plants, the Schiller Station, had a design efficiency of $36 \%$ with a mercury turbine inlet temperature of $514^{\circ} \mathrm{C}\left(958^{\circ} \mathrm{F}\right)$. The toxicity hazards of working with mercury, coupled with some technical difficulties, eliminated the cost advantages of employing higher efficiency mercury topping cycles over the less efficient steam systems. 


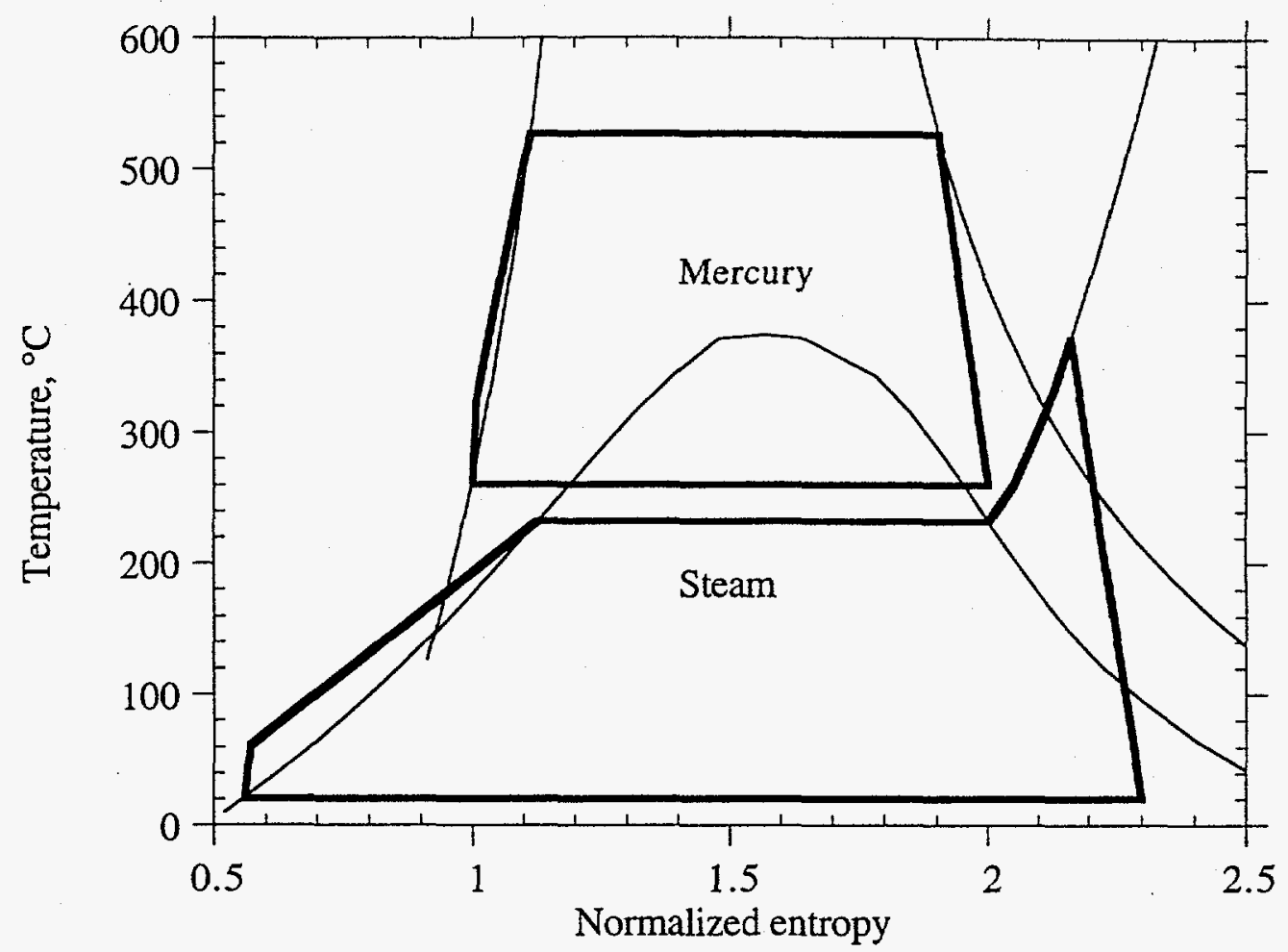

Figure 1. Temperature-entropy diagram for mercury topping cycle.

Rankine cycles employing potassium were proposed as topping cycles for supercritical steam systems, with achievable efficiencies of $53 \%$ indicated from analysis [Wilson, 1972; Fraas, 1982]. This would have been an efficiency gain of around ten points above the efficiencies of the plants operating at the time the analysis was performed. This relatively small efficiency gain coupled with economics probably doomed such a concept from actually being implemented. Figure 2 shows a temperature-entropy diagram for the cycle.

A consortium including Austria, the Federal Republic of Germany, and The Netherlands considered a three-module multiple Rankine topping cycle concept [Brockel et al., 1986]. The concept employed potassium in the high-temperature portion, diphenyl in the mid-temperature section, and steam in the low-temperature section, with a reported net efficiency of $51 \%$. Figure 3 shows the concept on a temperature-entropy diagram. The concept proposed a coal-fired potassium boiler 
delivering saturated potassium vapor at $870^{\circ} \mathrm{C}\left(1598^{\circ} \mathrm{F}\right)$ to an intermediate pressure potassium vapor turbine, then through three low pressure potassium vapor turbines in

- parallel due to the relatively high specific volume of potassium vapor, $56.2 \mathrm{~m}^{3} / \mathrm{kg}$ $\left(900 \mathrm{ft}^{3} / \mathrm{lb}\right)$, at an exhaust temperature of $477^{\circ} \mathrm{C}\left(891^{\circ} \mathrm{F}\right)$. The condensing potassium delivered heat to the boiling diphenyl at $455^{\circ} \mathrm{C}\left(851^{\circ} \mathrm{F}\right)$. The potassium cycle employed a single feedliquid heater. The potassium condenser/diphenyl boiler delivered saturated vapor to a turbine with extraction lines to four feedliquid heaters. The remaining vapor at the turbine exhaust condensed at $287^{\circ} \mathrm{C}\left(549^{\circ} \mathrm{F}\right)$ to vaporize steam at $270^{\circ} \mathrm{C}\left(518^{\circ} \mathrm{F}\right)$. The chosen fluids and arrangements dictated a relatively high cost with relatively little performance advantage over gas-turbine combined cycle plants.

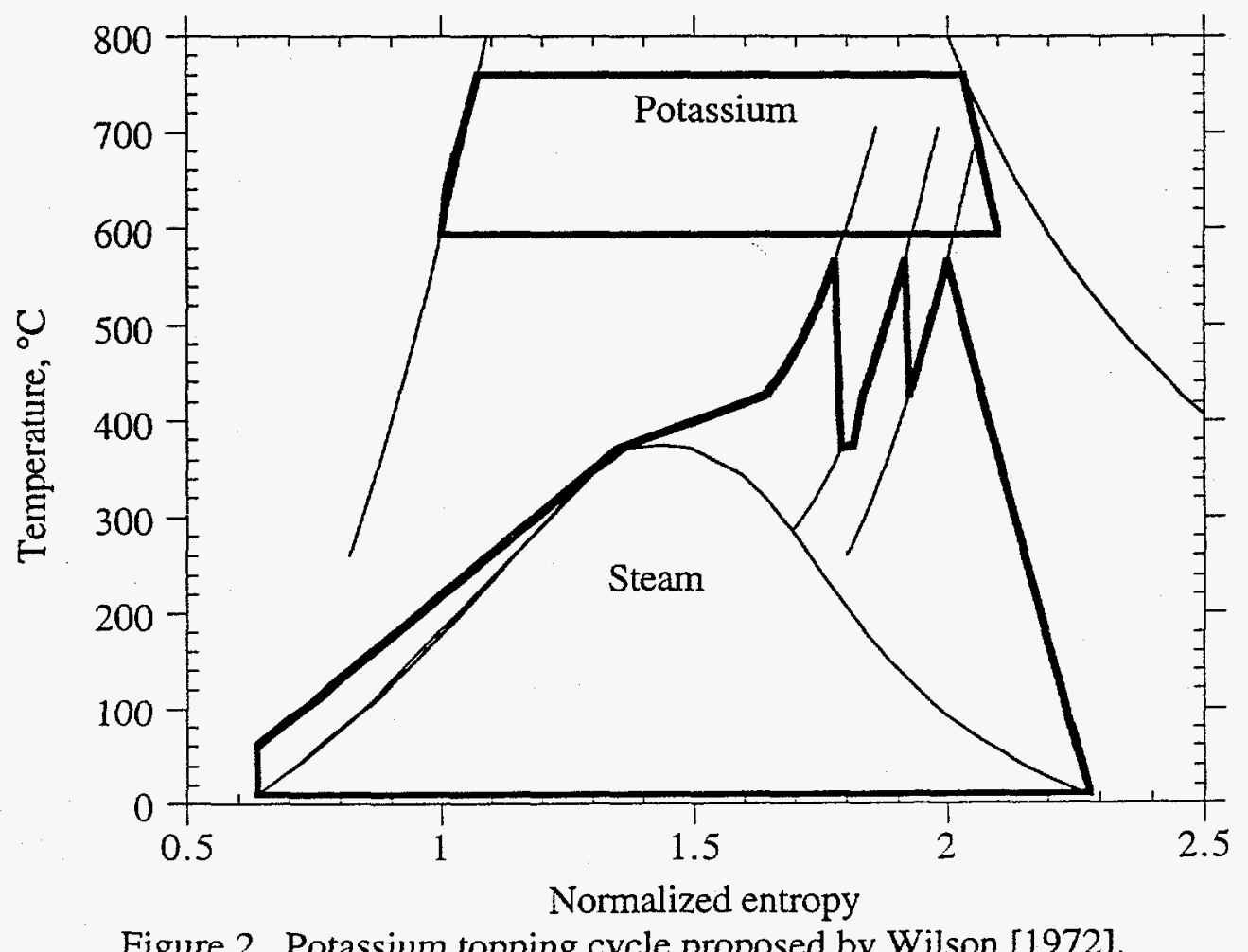

Figure 2. Potassium topping cycle proposed by Wilson [1972]. 


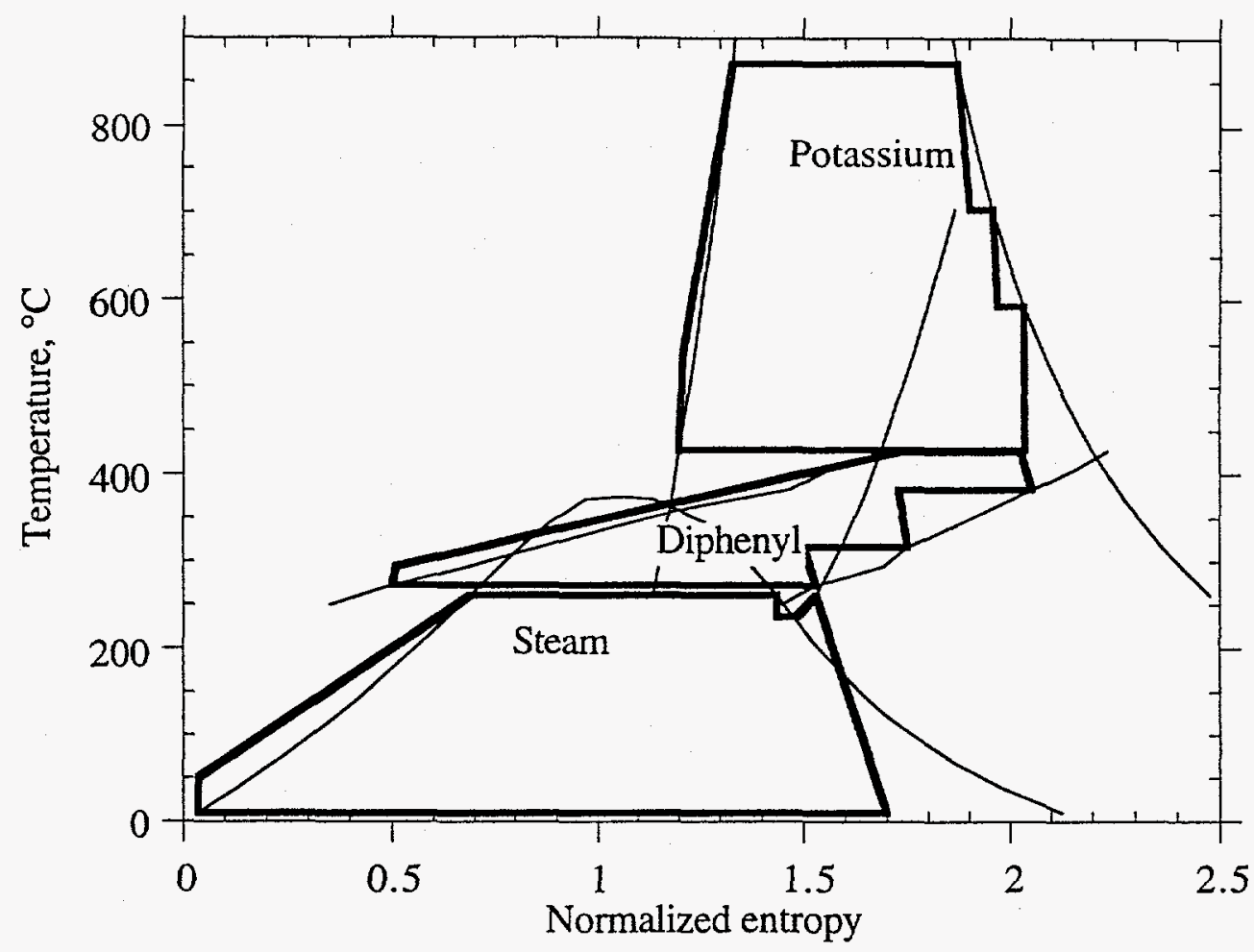

Figure 3. Temperature-entropy diagram for Austrian-Dutch-German concept.

The somewhat modest gains in efficiency achievable with any of the discussed topping cycles can be explained in terms of basic thermodynamics. The efficiency of a heat engine is primarily determined by the average temperatures at which heat is added and rejected. When the heat engine is comprised of sections with different working fluids, the area on a T-S diagram between the heat rejected from one cycle and the heat added to another cycle also bears upon the efficiency. That is, if a larger temperature difference exists between the heat rejection temperature of the hotter cycle and the heat addition temperature of the cooler cycle, greater irreversibility results, with a concomitant reduction in the efficiency. For the case of the mercury topping cycles, the mercury boiler outlet temperature was around $510^{\circ} \mathrm{C}\left(950^{\circ} \mathrm{F}\right)$, with heat rejected from the mercury at around $260^{\circ} \mathrm{C}\left(500^{\circ} \mathrm{F}\right)$ and heat added to the water around $232^{\circ} \mathrm{C}\left(450^{\circ} \mathrm{F}\right)$ [Hackett, 1951]. For the potassium topping cycle mentioned above, with boiler outlet temperatures of around $816^{\circ} \mathrm{C}\left(1500^{\circ} \mathrm{F}\right)$, poor use was made of the area between the 
water heat addition profile and the potassium heat rejection temperature: the potassium cycle heat rejection temperature was set at around $593^{\circ} \mathrm{C}\left(1100^{\circ} \mathrm{F}\right)$, while the

- supercritical steam cycle heat input temperature varied from $288^{\circ} \mathrm{C}\left(550^{\circ} \mathrm{F}\right)$ to $566^{\circ} \mathrm{C}$ $\left(1050^{\circ} \mathrm{F}\right)$, including reheats [Wilson, 1972]. The potassium cycle heat rejection temperature is limited primarily by the vapor pressure and vapor specific volume. Further reductions in the temperature could result in excessive in-leakage of air, and would increase the volumetric flow rates at the potassium turbine outlet and potassium condenser inlet.

\section{PROPOSED CONCEPT}

The proposed concept is motivated by the idea of filling in the gaps below the potassium cycles discussed above with the intermediate temperatures of a mercury cycle, and rejecting this heat to a non-supercritical steam cycle, and studying the effect of the various temperatures upon the cycle efficiency. A case study for a system employing sodium, mercury and water will be performed. Figure 4 shows a simplified representative $\mathrm{T}-\mathrm{S}$ diagram for the system. The choices of working fluids are somewhat arbitrary for this analysis, and fluids with well known properties were selected. However, the forthcoming analysis is applicable for any choice of working fluids, and so will be presented in terms of High Temperature (HT), Intermediate Temperature (IT), and Low Temperature (LT) modules. 


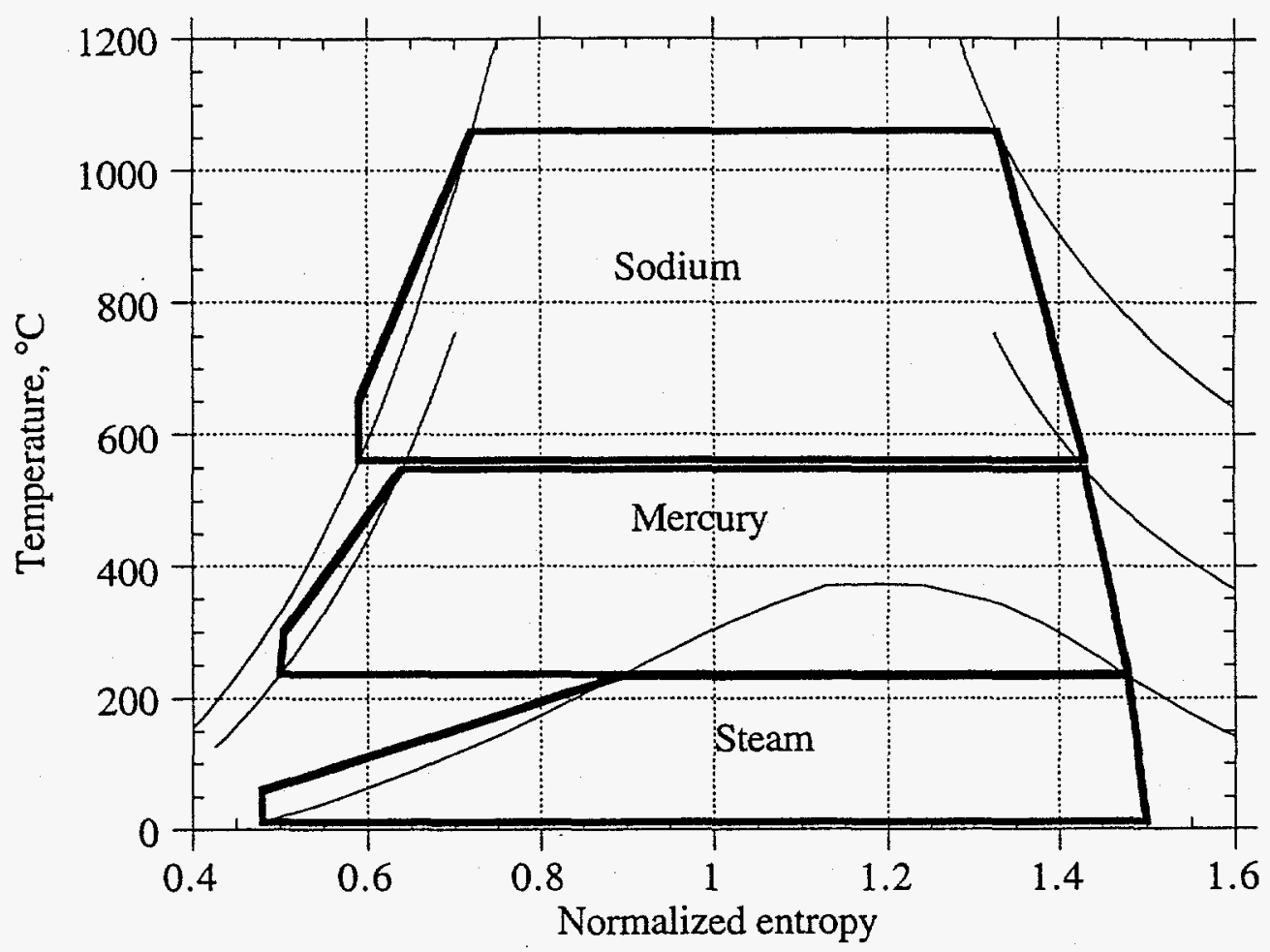

Figure 4. Temperature-entropy diagram for proposed concept.

\section{ANALYSIS}

The basis for an efficiency calculation is the ratio of the power sought to the power cost. For energy production, this is written as:

$$
\eta_{\text {overall }}=\frac{\text { net power output }}{\text { net heat input }}=\frac{\dot{\mathrm{W}}_{\text {net }}}{\dot{\mathrm{Q}}_{\mathrm{IN}, \text { net }}}
$$

For the case where the only heat input is to the high temperature cycle,

$$
\eta_{\text {overall }}=\frac{\dot{\mathrm{W}}_{\text {net, HT }}+\dot{\mathrm{W}}_{\text {net, IT }}+\dot{\mathrm{W}}_{\text {net, LT }}}{\dot{\mathrm{Q}}_{\mathrm{in}, \mathrm{HT}}}
$$

The following relations will be used: $\eta_{\alpha}=\frac{\dot{\mathrm{W}}_{\text {net, } \alpha}}{\dot{\mathrm{Q}}_{\mathrm{in}, \alpha}}, \dot{\mathrm{W}}_{\text {net, }, \alpha}=\dot{\mathrm{Q}}_{\mathrm{in}, \alpha} \alpha-\dot{\mathrm{Q}}_{\text {out },}$, , and 
$\frac{\dot{\mathrm{Q}}_{\text {out },} \alpha}{\dot{\mathrm{Q}}_{\text {in, } \alpha}}=1-\eta_{\alpha}$, where $\alpha=\mathrm{HT}, \mathrm{IT}$ or LT. Also note that $\dot{\mathrm{Q}}_{\text {out, }} \mathrm{HT}=\dot{\mathrm{Q}}_{\mathrm{in}, \text { IT }}$ and

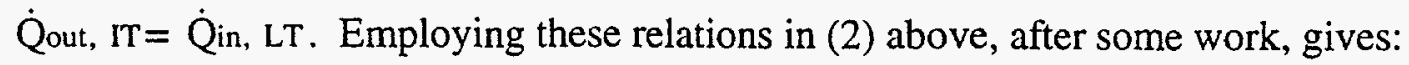

$$
\eta_{\text {overall }}=\eta_{\mathrm{HT}}+\left(1-\eta_{\mathrm{HT}}\left[\eta_{\mathrm{rT}}+\left(1-\eta_{\mathrm{rT}}\right)_{\mathrm{LT}}\right]\right.
$$

Note that, if only two working fluids were used, the result is $\eta_{\text {overall }}=\eta_{\mathrm{HT}}+\left(1-\eta_{\mathrm{HT}}\right) \eta_{\mathrm{LT}}$. Wilson [1972] shows a substantially equivalent equation. Also, note that

$$
\begin{aligned}
& \frac{\partial\left(\eta_{\text {overall }}\right)}{\partial\left(\eta_{\mathrm{HT}}\right)}=\left(1-\eta_{\mathrm{IT}}\right)\left(1-\eta_{\mathrm{LT}}\right) \\
& \frac{\partial\left(\eta_{\text {overall }}\right)}{\partial\left(\eta_{\mathrm{IT}}\right)}=\left(1-\eta_{\mathrm{HT}}\right)\left(1-\eta_{\mathrm{LT}}\right) \\
& \frac{\partial\left(\eta_{\text {overall }}\right)}{\partial\left(\eta_{\mathrm{LT}}\right)}=\left(1-\eta_{\mathrm{HT}}\right)\left(1-\eta_{\mathrm{IT}}\right)
\end{aligned}
$$

This information can be summarized by the single relation $\frac{\partial\left(\eta_{\text {overall }}\right)}{\partial\left(\eta_{\alpha}\right)}=\left(1-\eta_{\beta}\right)\left(1-\eta_{\chi}\right)$ where all the subscripts range over HT, IT and LT, and $\alpha \neq \beta \neq \chi$. This relationship is shown in Figure 5 below. The figure shows a really basic concept: the impact upon the overall efficiency of changing a single module efficiency is largest when the other efficiencies are smallest. 


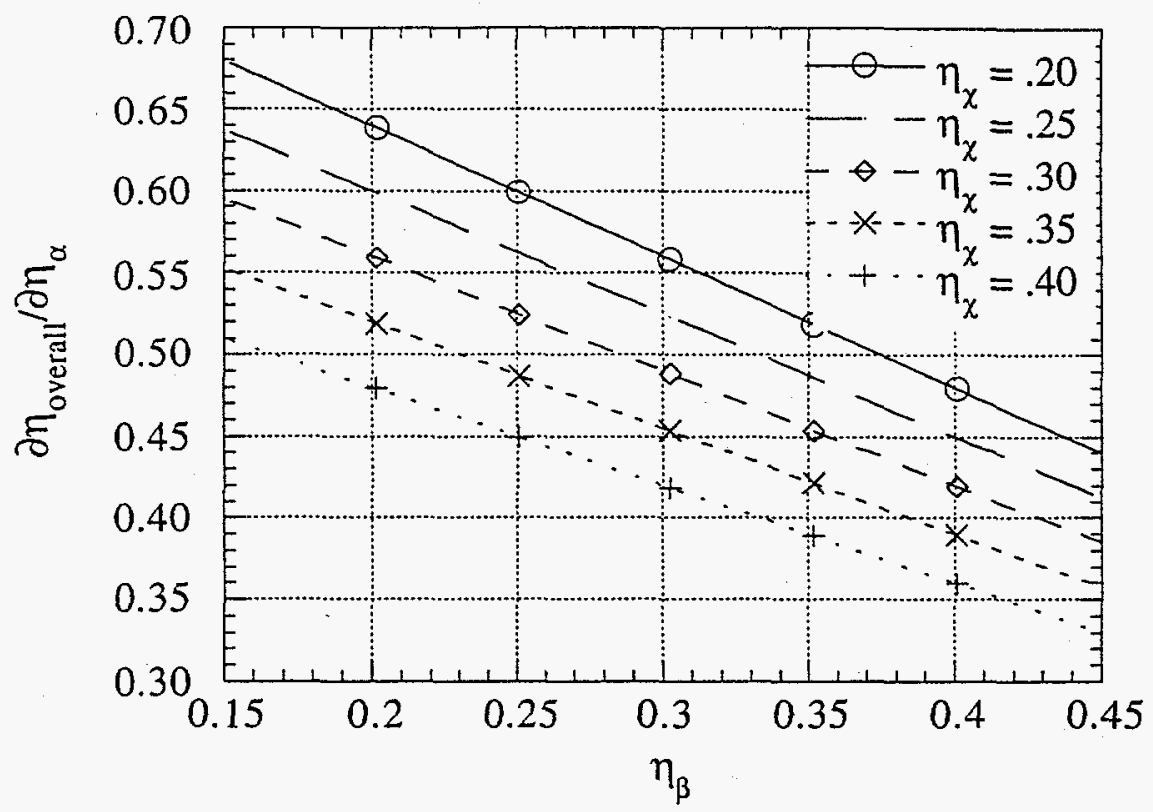

Figure 5. Effect of single module efficiency gradient on overall efficiency.

CASE STUDY: Simple Rankine Cycles with $\mathrm{Na}, \mathrm{Hg}$, and $\mathrm{H}_{2} \mathrm{O}$ as working fluids.

In order to demonstrate the achievable efficiencies for this concept, sodium will be employed as the higher temperature working fluid, with mercury and water as the intermediate and low temperature working fluids, respectively. The cases studied here include a steam condenser pressure of $\approx 6.9 \mathrm{kPa}(1.0 \mathrm{psia})$ with a saturation temperature of $38.7^{\circ} \mathrm{C}\left(101.7^{\circ} \mathrm{F}\right)$. The parameters to be varied include the sodium boiler outlet temperature and the mercury and water heat addition temperatures, $\mathrm{T}_{\text {high,Hg}}$ and $\mathrm{T}_{\text {high,steam }}$. The thermodynamic properties are from Van Wylen and Sonntag [1973], El. Wakil [1984] and Howell and Buckius [1987] for mercury, sodium and water, respectively. Assumed throughout are pump efficiencies of $80 \%$ and turbine efficiencies of $90 \%$. The cases of simple Rankine cycles only are covered, that is, no feedliquid heaters, no reheat and no superheat. The impact of these 
modifications is seed for future work. The boiler efficiency is neglected in this work. The results are presented in Figure 6 below.

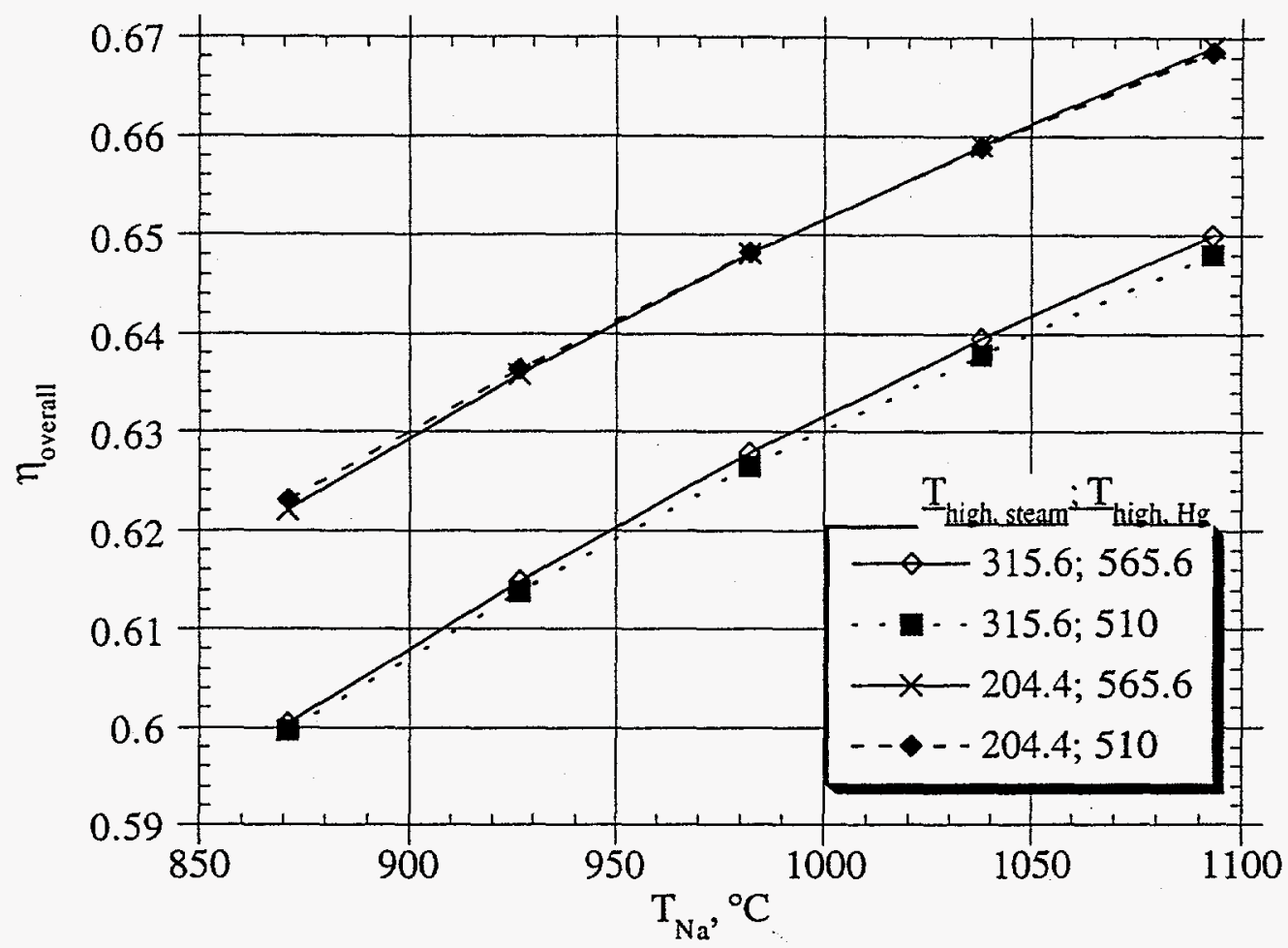

Figure 6. Overall efficiency versus sodium temperature, various $\mathrm{T}_{\text {high,Hg }}$ and $\mathrm{T}_{\text {high,H2O}}, \Delta \mathrm{T}=27.8^{\circ} \mathrm{C}\left(50^{\circ} \mathrm{F}\right)$.

The marked difference in efficiency for the two steam temperatures in the figure is primarily due to the high specific heat of saturated liquid water. This property causes the efficiency of the steam cycle to be significantly below the Carnot cycle efficiency between the same temperature limits. The extremely low saturated liquid specific heats for mercury and sodium also explain the very small effect of varying the sodium condensing/mercury boiling temperature upon the overall efficiency as shown in the figure. The low specific heats for these fluids cause much less deviation from a Carnot cycle efficiency, with the imperfect turbine efficiency acting as the largest source of said deviation. 


\section{CONCLUSION}

An analysis has been performed to allow computation of the overall thermal efficiency of a multiple module plant in terms of the thermal efficiencies of the individual modules. The result is allowing one to "decouple" the calculation process between the modules. A case study shows an overall cycle efficiency of $67 \%$ at a heat addition temperature of $1093^{\circ} \mathrm{C}\left(2000^{\circ} \mathrm{F}\right)$. However, the intermediate fluid used in the case study, mercury, is probably not a viable power plant working fluid. The rather high efficiencies predicted represent significant improvements in thermal efficiencies compared with present plants. However, actually exploiting these higher efficiencies in a power station is a sobering prospect because of the reactivity hazards associated with the alkali metals, and difficulties associated with materials requirements.

\section{BIBLIOGRAPHY}

Brockel, D., A. Lang, N. Schwarz, H. Stehle, I. Wolter and N. Woudstra, 1986, “Treble Rankine Cycle Project Summary Report," BMFT-FB-T-86-046. El. Wakil, M.M., [1984], Power Plant Technology, John Wiley \& Sons, New York.

Fraas, A.P., 1982, Engineering Evaluation of Energy Systems, McGraw-Hill, Inc., New York.

Hackett, H.N., 1951, "Mercury-Steam Power Plants," Mechanical Engineering, July, $559-64$.

Holcomb, R.S., 1982, “Alkali Metal Rankine Topping Cycle System Design and Development," Proceeding of the 17th Intersociety Energy Conversion Engineering Conference.

Howell, J.R., and R.O. Buckius, 1987, Fundamentals of Engineering Thermodynamics, English/SI version, McGraw-Hill, Inc., New York. Kartha, S. and P. Grimes, 1994, "Fuel Cells: Energy Conversion for the Next 
Century," Physics Today, November, 54-61.

Van Wylen, R.E., and G.J. Sonntag [1973], Fundamentals of Classical Thermodynamics, John Wiley and Sons, New York.

Wilson, A.J., 1972, "Space Power Spinoff Can Add 10+ Points of Efficiency to Fossil-Fueled Power Plants," Proceedings of the 7th Intersociety Energy Conversion Engineering Conference, San Diego, CA, Sept. 25-29, pp. 260-8. 